\title{
Colibacillosis and Antibiotics Resistance Patterns in Broiler
}

\author{
Chotiah S, Damayanti R \\ Indonesian Research Center for Veterinary Science \\ Jl. RE Martadinata No. 30, Bogor 16114, West Java, Indonesia \\ sitichoti@yahoo.co.id
}

\begin{abstract}
Colibacillosis is considered important in the poultry industry because it generates economic losses due to the disturbance of growth, the decline in production, an increase number of culled chicken, and reduced quality of carcasses and eggs. Study of colibacillosis and antibiotics resistance patterns in broiler was conducted at the Indonesian Research Centre for Veterinary Science. The aim of the study was to provide the latest information on the status of the presence of Escherichia coli in broiler farms in four districts in West Java Province as well as its antibiotics drug resistance patterns and their pathogenicity will be studied. A total of 196 samples of the intestine, liver, heart, egg yolk, air sac that showed gross abnormalities were sampled and feces were collected and used in this study. Escherichia coli was isolated for characterisation and antibiotics drug resistance patterns and their pathogenicity were investigated. Escherichia coli were recovered from $149(76.02 \%)$ samples out of the total samples collected. In this present study, one (7.7\%) E. coli isolate was serologically typed into $\mathrm{O}_{78}$ and 12 of them were untypable whereasthe other 7 (4.93\%) isolates were serologycally typed into $\mathrm{O}_{157}$ and 135 were untypable. In vitro pathogenicity indicated that $91.55 \%$ of the isolates were positive for Congo red binding assay and 4.93\% isolates were positive for haemolysine production. Antibiogram profiles indicated that 98.70, 79.30, 75.10, 61.40, and 57.70\% isolates were resistance against to amphicillin, neomycin, streptomycin, sulfamethoksazol trimethropim, and kanamycin, respectively. A total of 149 $(76,02 \%)$ histopathologically had consistent colibacillos is lesion with various degree of severity.
\end{abstract}

Key Words: Colibacillos is, Broiler, Resistance, Antibiotics

\section{INTRODUCTION}

Escherichia coli (E. coli) is one of the most economically important bacteria which is responsible for early chick mortality in poultry farms. Escherichia coli is normal microflora in the digestive tract of animals and human, but certain strains that are pathogenic in birds are called avian pathogenic E. coli (APEC). They are able to spread to various organs and cause systemic and fatal colibasillosis (Barnes et al. 2013). In general, pathogenic $E$. coli in poultry has specific serotypes, mostly consisted of serotype as follows: $\mathrm{O}_{78}, \mathrm{O}_{1}$, and $\mathrm{O}_{2}$, and under certain condition includes $\mathrm{O}_{15}$ and $\mathrm{O}_{55}$ (Barnes et al. 2013).

Colibacillosis in poultry industry is worldwide (Delicato et al. 2003; Ewers et al. 2004). The disease remains a major problem in the poultry industry because it generates economic losses due to the disturbance of growth, the decline in production, an increase in the number of culled chicken, and reduce quality of carcasses and eggs (Barnes et al. 2013).

Accordingly, APEC needs more attention as several studies have shown no association with extra intestinal pathogenic E. coli (ExPEC) in humans, especially uropathogenic E. coli (UPEC) and neonatal meningitis E. coli (NMEC). This indicates that some APEC strains could be considered potential zoonosis as gen (Ewers et al. 2007; Moulin-Schouleur et al. 2007; Johnson et al. 2008).

Colibacillosis in Indonesia was first found at a farm in Bogor attacking $27.3 \%$ broiler aged 5-32 weeks (Poernomo 1988). Purnomo \& Juarini (1996) have isolated 950 E. coli isolates, and have been classified into serotypes: $\mathrm{O}_{1} \mathrm{~K}_{1}: 85$ cases $(9.0 \%), \mathrm{O}_{2} \mathrm{~K}_{1}: 489$ cases $(51.5 \%) ; \mathrm{O}_{78} \mathrm{~K}_{80} ; 101$ cases $(10.6 \%)$ and other serotypes: 275 (28.9\%). Recently, it has 
have been reported that E. coli serotype $\mathrm{O}_{1}, \mathrm{O}_{2}$ and $\mathrm{O}_{78}$ were identified from colibacillosis cases in chickens farm in Yogyakarta (Wahyuwardani et al. 2014). Prompt diagnosis and treatment of colibacillosis are crucial to ensure optimal productivity in poultry farms. The aim of the study was to provide the latest status of colibacillosis in broiler farms in four districts in West Java Province as well as its antibiotics drug resistance patterns and their pathogenicity will be studied

\section{MATERIAL AND METHODS}

\section{Sample collection}

Samples were collected from some broiler farms heaving population range of 3,000 to 30,000, located in four districts in West Java Province, namely: Bogor, Sukabumi, Cianjur and West Bandung in 2014. The samples collected were as follows: intestine, liver, heart, air sac, egg yolk derived from sick or recently dead chickens. Any organs showing any gross lesion were sampled, as well as faecal samples were collected from suspected cages. Samples for E. coli isolation were placed in a cool ice box and transported to the laboratory whereas samples for histopathology were fixed in buffered neutral formalin $10 \%$.

\section{Isolation and identification}

Isolation and identification of $E$. coli was conducted by standard methods with slight modification by using a specific medium according to Barrow \& Feltham (2009). Each organ of the samples were diluted with buffer peptone water $(0.5 \mathrm{~g} / 4.5 \mathrm{ml})$ using a stomacher "80", then incubated at $37^{\circ} \mathrm{C}$ overnight. The day after, $0.5 \mathrm{ml}$ of the suspension was grown in a solid medium Tryptone Bile salt X-glucuronide (TBX) and incubated at $37^{\circ} \mathrm{C}$ for 24 hours. Suspected green colony of pure E. coli was stained with Gram and the morphology examined under the microscope. Biochemical characteristics were performed using identification device of API $20 \mathrm{E}$ (Biomereux, France).

\section{Serotyping}

Each isolate of pure E. coli serotypes was determined by standard methods slide agglutination according to Murray (1984) using specific antisera of $\mathrm{O}_{1}, \mathrm{O}_{78}, \mathrm{O}_{2}$ and produced by Indonesian Research Center for Veterinary Science (IRCVS). Serological test against specific $\mathrm{O}_{157}$ antisera was obtained by latex agglutination test using commercial antisera (Oxoid, England).

\section{In vitro pathogenicity testing}

Pathogenic or nonpathogenic E. coli can be distinguished in vitro by using invasive nature of the Congo Red dye binding test (Sharma et al. 2006) and the nature to produce haemolysin (Panigraphy \& Ling 1990).

\section{Haemolysis production test}

Eschechia coli isolates were grown in 5\% solid medium of sheep blood, and then incubated at $37^{\circ} \mathrm{C}$ for 24 hours. Colonies showing a clear zone (hemolysis) showed a positive haemolysin (Panigraphy \& Ling 1990). 


\section{Congo reddye binding test}

Eschechia coli isolates were grown in a solid medium of Congo Red Trypticase Soy agar added with $0.003 \%$ Congo Red dye (Sigma) and $0.15 \%$ bile salts (OXOID), incubated at $37^{\circ} \mathrm{C}$ for 24 hours, then stored at room temperature for 48 hours. Invasive isolates will indicated by the colony's ability to absorb Congo Red dye during 72 hours observation period. Red color indicates a positive whereas colorless means negative isolates (Sharma et al. 2006).

\section{Antibiogram}

Each E. coli isolates were tested its sensitivity to several kinds of antibiotics using Kirby-Bauer method disk diffusion susceptibility (Jorgensen \& Turnidge 2007), modified with solid medium trypticase soy (TS) by placing antibiotics discs. A total of seven commercial antibiotics recommended for Gram-negative bacteria (Oxoid, England) was used in this test, namely: Gentamicin (CN) $10 \mu \mathrm{g}$, Chloramphenicol (C) $30 \mu \mathrm{g}$, Ampicillin (Amp) $10 \mu \mathrm{g}$, Kanamycin (K) 30 $\mathrm{gg}$, Streptomycin (S) $10 \mu \mathrm{g}$, Sulfamethoksazol Trimethropim (SXT) $25 \mu \mathrm{g}$, Neomisin (N) $10 \mu \mathrm{g}$, Sulfamethoksazol Trimethropim (SXT) $25 \mu \mathrm{g}$ and Streptomicin (S) $10 \mu \mathrm{g}$ ).

\section{Clinicopathological examination}

Clinical symptoms and gross lesions from sick and dead chicken were observed and recorded. Samples were fixed in neutral buffered formalin solution (BNF) 10\%, then processed as paraffin blocks, cut at 3-4 $\mu \mathrm{m}$ thick and stained with H\&E methods. Histopathological examination (HP) is performed using hematoxylin and eosin staining (H\&E) according to standard procedures (Kumar \& Kieman 2010). Examination of histopathological findings were assessed microscopically and lesions were analyzed descriptively.

\section{RESULTS AND DISCUSSION}

In this study, random sampling was collected from 36 broiler farms in four districts in West Java Province. Eighty-nine broiler consisting of 56 sick birds and 33 dead chicken were collected and necropsies were carried out. A total of 186 samples of the intestine, liver, heart, egg yolk, air sac that showed gross lesions consistent with colibacillosis were sampled and 10 faeces were collected for this study (Table 1).

Tabel 1. Total sample collected for detection of pathogenic E. coli isolates

\begin{tabular}{|c|c|c|c|c|c|c|c|c|c|}
\hline \multirow{3}{*}{ Distric/total farms } & \multicolumn{9}{|c|}{ Total of sample } \\
\hline & \multicolumn{2}{|c|}{ Chicken } & \multicolumn{6}{|c|}{ Gross lesion } & \multirow[t]{2}{*}{ Total } \\
\hline & Sick & $\overline{\text { Dead }}$ & Intestine & Liver & Heart & Egg yolk & Air sac & Feces & \\
\hline$\overline{\text { Bogor/9 }}$ & 11 & 13 & 24 & 5 & 3 & 6 & 2 & 4 & 44 \\
\hline Sukabumi/13 & 13 & 9 & 22 & 14 & 4 & 6 & 4 & 4 & 54 \\
\hline Cianjur/3 & 4 & 4 & 8 & 7 & 6 & 0 & 1 & 2 & 24 \\
\hline West Bandung/11 & 28 & 7 & 35 & 25 & 1 & 13 & 0 & 0 & 74 \\
\hline Total/36 & 56 & 33 & 89 & 51 & 14 & 25 & 7 & 10 & 196 \\
\hline
\end{tabular}


The characterization of $E$. coli isolated from septicemic sick and dead chickens collected from four districts in West Java was shown in Table 2. Escherichia coli was recovered from $149(76,02 \%)$ samples out of the total 196 samples collected. In the present study, one $(7.7 \%)$ E. coli isolate was typed serologycally into $\mathrm{O}_{78}$ and 12 were untypable. The other 7 (4.93\%) isolates were typed serologycally into $\mathrm{O}_{157}$ and 135 were untypable.

While pathogenic or non pathogenic $E$. coli can be distinguished in vitro by using invasive nature of the Congo Reddye binding test and the nature to produce haemolysis, in terms of clinico-pathological findings, there were several pathognomonic lesions. The clinical evidence showed depression, weakness associated with respiratory distress and non-uniform growth rate (Khaton et al 2008). The results of the Congo red binding assay indicated that majority $(91.55 \%)$ were positif and only 12 isolates were negative. Seven of 142 isolates recovered tested were positive for haemolysine production.

Tabel 2. Characterization of $E$. coli isolated from septicaemic sick and dead chickens collected from four districts in West Java Province

\begin{tabular}{|c|c|c|c|c|c|c|c|c|}
\hline \multirow{3}{*}{ District } & \multirow{3}{*}{\multicolumn{2}{|c|}{$\begin{array}{cc}\text { Total } & \text { Positive } \\
\text { samples/chicken for } E \text {. coli }\end{array}$}} & \multicolumn{6}{|c|}{ Characteristic E. coli (number positive/number tested) } \\
\hline & & & \multirow{2}{*}{$\alpha$ haemolysis } & \multirow{2}{*}{ CR invasive } & \multicolumn{4}{|c|}{ Serotype } \\
\hline & & & & & $\mathrm{O}_{1}$ & $\mathrm{O}_{2}$ & $\mathrm{O}_{78}$ & $\mathrm{O}_{157}$ \\
\hline Bogor & $44 / 24$ & 33 & $0 / 33$ & $30 / 33$ & $0 / 1$ & $0 / 1$ & $0 / 1$ & $4 / 33$ \\
\hline Sukabumi & $54 / 22$ & 31 & $0 / 25$ & $18 / 25$ & $0 / 2$ & $0 / 2$ & $0 / 2$ & $1 / 25$ \\
\hline Cianjur & $24 / 8$ & 22 & $4 / 22$ & $22 / 22$ & $0 / 5$ & $0 / 5$ & $1 / 5$ & $1 / 22$ \\
\hline West Bandung & $74 / 35$ & 63 & $3 / 62$ & $60 / 62$ & $0 / 5$ & $0 / 5$ & $0 / 5$ & $1 / 62$ \\
\hline Total & $196 / 89$ & 149 & $7 / 142$ & $130 / 142$ & $0 / 13$ & $0 / 13$ & $1 / 13$ & $7 / 142$ \\
\hline
\end{tabular}

CR: Congo red

The sensitivity and resistance pattern of these isolates for various antibiotics are presented in Tabel 3. It was observed that 98.70, 79.30, 75.10, 61.40, and 57.70\% isolates were resistance against amphicillin, neomycin, streptomycin, sulfamethoksazol trimethropim, and kanamycin, respectively. We also found multiple antibiotics resistance among several E. coli isolates from septicaemic sick and dead chikens collected from three districts in West Java can be seen in Figure 1.

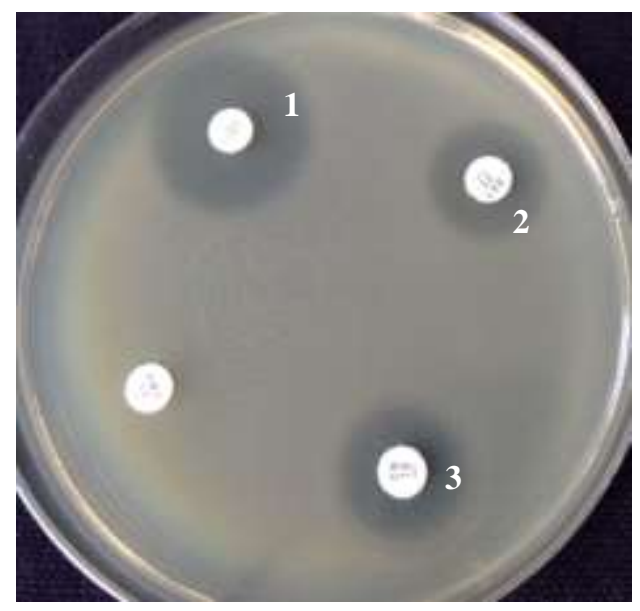

Figure 1. Antimicrobial sensitivity test for E. coli on Meuller Hinton agar E. coli zone to Cloramphenicol (1), Sulfamethoksazol Trimethropim (2), Neomycin (3) 
Tabel 3. Antibiotics sensitivity $E$. Coli isolates from septicaemic sick and dead chikens collected from three districts in West Java

\begin{tabular}{lclrrrrrrr}
\hline \hline \multirow{2}{*}{ District } & \multirow{2}{*}{$\begin{array}{c}\text { No. of } \\
\text { isolate }\end{array}$} & $\begin{array}{c}\text { Average sensitivity } \\
\text { test (\%) }\end{array}$ & \multicolumn{1}{c}{ Antibiotics } \\
\cline { 3 - 9 } & & & \multicolumn{1}{c}{$\mathrm{A}$} & \multicolumn{1}{c}{$\mathrm{C}$} & $\mathrm{G}$ & \multicolumn{1}{c}{$\mathrm{K}$} & $\mathrm{N}$ & \multicolumn{1}{c}{$\mathrm{ST}$} & \multicolumn{1}{c}{$\mathrm{S}$} \\
\hline West Bandung & 33 & Resistant & 100.0 & 24.2 & 39.4 & 72.7 & 84.9 & 81.8 & 78.80 \\
& & Intermediate & 0.0 & 27.3 & 15.1 & 27.3 & 15.1 & 3.0 & 18.20 \\
& & Sensitive & 0.0 & 48.5 & 45.5 & 0.0 & 0.0 & 15.2 & 3.00 \\
Sukabumi & \multirow{2}{*}{26} & Resistant & 96.2 & 88.5 & 30.8 & 38.5 & 76.9 & 69.2 & 84.60 \\
& & Intermediate & 3.8 & 7.7 & 11.5 & 53.8 & 23.1 & 23.1 & 7.70 \\
& & Sensitive & 0.0 & 3,8 & 57.7 & 7.7 & 0.0 & 7.7 & 7.70 \\
Cianjur & \multirow{2}{*}{21} & Resistant & 100.0 & 0.0 & 4.8 & 61.9 & 76.2 & 33.3 & 61.90 \\
& & Intermediate & 0.0 & 0.0 & 4.8 & 38.1 & 23.8 & 38.1 & 19.05 \\
& & Sensitive & 0.0 & 100.0 & 90.4 & 0.0 & 0.0 & 28.6 & 19.05 \\
Total & Resistant & 98.7 & 37.6 & 25.0 & 57.7 & 79.3 & 61.4 & 75.10 \\
& & Intermediate & 1.3 & 11.6 & 10.5 & 39.6 & 20.7 & 21.4 & 15.00 \\
& & Sensitive & 0.0 & 50.8 & 64.5 & 2.7 & 0.0 & 17.2 & 9.90 \\
\hline
\end{tabular}

A: Amphicillin; C: Chloramphenicol; G: Gentamycin; K: Kanamycin; N: Neomycin; ST: Sulfamethoksazol trimethropim; S: Streptomycin

It shows that $E$. coli is sensitive to chloramphenicol and resistant to amphicillin, neomycin and sulfamethoksazol trimethropim. This resistance of E. coli was previously reported by Kabir (2010) that avian pathogenic E. coli strains were often resistant to antimicrobials approved for poultry including cephradine, tetracyclines, chloramphenicol, sulfonamides, amino-glycosides, $\beta$-lactam antibiotics as well as for fluoroquinolones.

Postmortem examination showed evidence of fibrinous hepatitis, pericarditis, peritonitis and air sacculitis as the major findings observed (Abu Daud et al. 2014). Associated histopathological lesions represented the degree of severity of the lesions, in correlation with the pathogenicity of the isolate. Figure 2 shows the most consistent lesions found in this study. This was in accordance with non-suppurative pericarditis, hepatitis and enteritis were pathognomonic lesions caused by Colibacillosis reported by Abu Daud et al. (2014). 

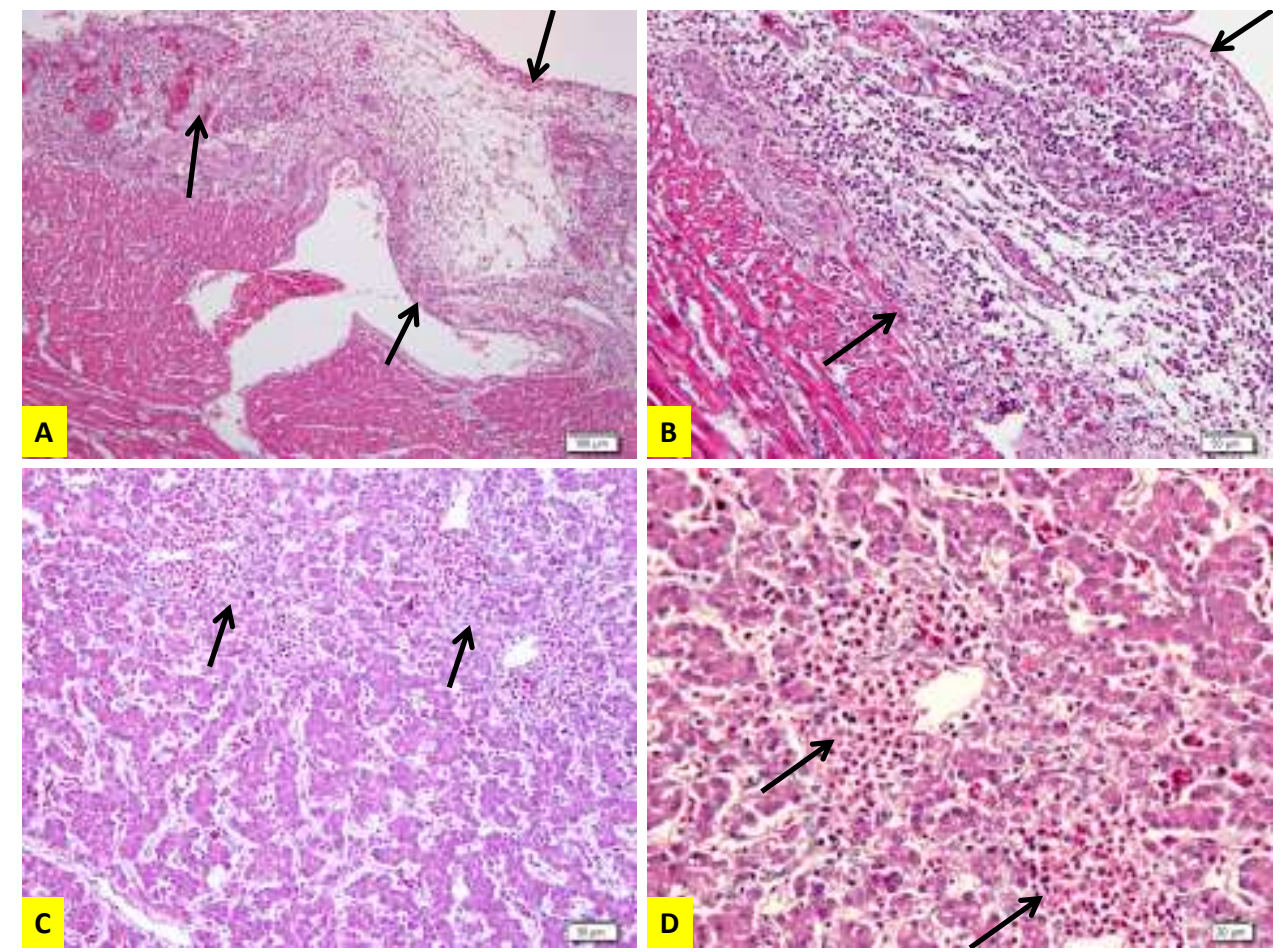

A. Pericarditis, chicken AH2: edematous, heterophils infiltration and necrotizing pericarditis; B. Higher magnification of A; C. Hepatitis, chicken AH2: heterophil infiltration; D. Higher magnification of $\mathrm{A}$

Figure 2. Colibacillosis

\section{CONCLUSION}

Most of isolated E. coli in this study were pathogenic and responsible for various types of leading to economic losses in poultry industry. The antibiotics sensitivity pattern revealed that isolated E. coli were resistance to several antibiotis. Therefore, a particular emphasis attention needs to be taken judiciously to select the antibiotics, especially after antibiotics sensitivity testing. Optimum antibiotic dose during sufficient time was needed to ensure effective treatment and control for colibacillosis in poultry. A better understanding addressed in this study will assist the poultry industry in reducing and eliminating avian colibacillosis from the poultry flocks, thereby reducing potential hazards to the public health posed by the bacterial diseases.

\section{REFERENCES}

Abu Daud NHb, Htin NN, Abba Y, Paan FH, Kyaw T, Khaing AT, Abdullah FFJ, Mohammed K, Adam L, Tijjani A. 2014. An Outbreak of Colibacillosis in a BroilerFarm. J VetAdv. 2014, 4(7):648-653. DOI:10.5455/jva.20140713052735

Barrow GI, Fetham RKA. 2009. CowanandSteel'S. Manual for the Identification of Medical Bacteria. 3rd ed. Cambridge University Press, UK. p. 118-119.

Barnes HJ, Nolan LK, Vaillancourt. 2013. Colibacillosis. In Swyne DE, Glisson JR, Mc Dougald LR, Nolan LK, Suarez DC, Nail P, editors. Diseases of Poultry.13nd ed. Amerika. WILEY_BLACKWELL Publishing. p. 691-725.

Delicato ER, de Brito BG, Gaziri LC, Vidotto MC. 2003. Virulence associated genes in Escherichia coli isolates from poultry with colibacillosis. Vet. Microbiol. 94:97-103. 
Ewers C, JanBen T, KieBling S, Philipp HC, Wieler LH. 2004. Molecular epidemiology of avian pathogenic Escherichia coli (APEC) isolated from colisepticemia in poultry. Vet. Microbiol. 104:91-101.

Ewers C, Li G, Wilking H, Kiessling S, Alt K, Antáo E.M, LaturnusC, Diehl I, Glodde S, Homeier T, Böhnke U, Steinrück H, PhilippHC, Wieler LH. 2007. Avian pathogenic, uropathogenic, andnewborn meningitis-causing Escherichia coli: how closely related arethey? Int. J. Med. Microbiol. 297:163-176.

Johnson TJ, Wannemuehler Y, Johnson SJ, Stell AL, Doetkott C, Johnson JR, Kim KS, Spanjaard L \& Nolan LK. 2008. Comparison of extraintestinal pathogenic Escherichia coli from human and avian sources reveals a mixed subset representing potential zoonotic pathogens. Appl. Environ. Microbiol. 74:7043-7050.

Jorgensen JH, Turnidge JD. 2007. Susceptibility test methods: dilution and disk diffusion methods. In Murray PR, Baron EJ, Jorgensen JH, Landry ML, Pfaller MA, editors. Manual of clinical microbiology, 9th ed. ASM Press, Washington, D.C. p. 1152-1172.

Kabir SML. 2010. Avian Colibacillosis and Salmonellosis: A Closer look at Epidemiology, Pathogenesis, Diagnosis, Control and Publeaic Halth Conserns. Int J Environ Res Public Health. 7(1):89-114.

Khaton R, Haider MG, Paul PK, Das PM, Hosain MM. 2008. Colibacillosis in Commercial Chicken in Bangladesh. The Bangladesh Veterinarian 25(1):17-24

Kumar GL, Kieman JA. 2010. Education Guide-Special Stains and H \& E. 2nd ed. Carpinteria (USA): Dako North America.

Moulin-Schouleur M, Répérant M, Laurent S, Brée A, Mignon-GrasteauS, Germon P, Rasschaert D, Schouler C. 2007. Extraintestinal pathogenic Escherichia coli strains of avian and human origin: link between phylogenetic relationships and common virulence patterns. J Clin Microbiol. 45:3366-3376.

Panigraphy B, Ling Y. 1990. Differentiation of pathogenic and nonpathogenic Escherichia coli isolated from poultry. Avian Dis. 34:941-943.

Poernomo S. 1988. Infeksi Escherichia coli pada sebuah peternakan ayam pedaging di daerah Bogor, Jawa Barat. Penyakit Hewan. 20:8-12.

Purnomo S, Juarini E. 1996. Penyebaran Escherichia coli sero tipe O1K1, 02K1 dan O78K80 pada ayam di Indonesia. JITV. 1:194-199.

Sharma KK, Soni SS, Meharchandani S. 2006: Congo red dye agar test as an indicator test for detection of invasive bovine Escherichia coli. Vet Arhiv. 76:363-366.

Wahyuwardani S, Noor SM, Poeloengan M, Andriani, Aryanti T. 2014. Kasus Kolibasillosis pada peternakan ayam di Yogyakarta dan Bogor. In: Pamungkas D, Widiawati Y, Noor SM, Purwantari ND, Widiastuti R, Brahmantyo B, Herawati T, Kusumaningsih A, Handiwirawan E, Puastuti W, penyunting. Teknologi Peternakan dan Veteriner Mendukung Pertanian Bioindustri Berkelanjutan. Prosiding Seminar Nasional Teknologi Peternakan dan Veteriner. Malang, 12-14 Agustus 2014. Bogor (Indonesia): Puslitbangnak. p. 606-610. 